\title{
Correction to: Emotions and Cognitions in Early Childhood Aggression: the Role of Irritability and Hostile Attribution Biases
}

\author{
Gretchen R. Perhamus ${ }^{1}$. Jamie M. Ostrov ${ }^{1}$
}

(c) Springer Science+Business Media, LLC, part of Springer Nature 2020

\section{Correction to: Journal of Abnormal Child Psychology} https://doi.org/10.1007/s10802-020-00707-7

In the recently published article "Emotions and Cognitions in Early Childhood Aggression: the Role of Irritability and Hostile Attribution Biases" Figure captions (under Figs. 1 and 2) and notes within the figures are redundant. These notes should be deleted.

The original article has been corrected.

Publisher's note Springer Nature remains neutral with regard to jurisdictional claims in published maps and institutional affiliations.

The original article can be found online at https://doi.org/10.1007/ s10802-020-00707-7

Gretchen R. Perhamus

grperham@buffalo.edu

1 Department of Psychology, University At Buffalo, The State University of New York, 475 Park Hall, Buffalo, NY 14260, USA 